\title{
Assessment of Different Sowing Dates and Varieties on Growth, Yield and Quality of Seed in Garden Pea (Pisum sativum L.)
}

\author{
Sonam Sirwaiya ${ }^{*}$ and S.S. Kushwah \\ Department of Vegetable Science, College of Horticulture, Mandsaur, Rajmata Vijayaraje \\ Scindia Krishi Vishwa Vidyalaya, Gwalior-(Madhya Pradesh), India \\ *Corresponding author
}

\section{Ke y w ords \\ Pea (Pisum sativum \\ L.), Sowing date, \\ Variety, Growth, Yield, Quality \\ Article Info \\ Accepted: \\ 12 February 2018 \\ Available Online: \\ 10 March 2018}

\section{A B S T R A C T}

It is resulted that the growth characters of pea indicated significant effect of sowing dates as sowing dates, $D_{1}\left(1^{\text {st }}\right.$ November) had recorded maximum plant height, number of leaves, number of branches, earliest 50\% flowering and harvesting and SPAD value at all the growth stages, while minimum in $\mathrm{D}_{4}\left(16^{\text {th }}\right.$ December $)$ date of sowing. Yield attributes traits revealed significant impact of date of sowing in garden pea. Highest number of pods per plant was recorded under $\mathrm{D}_{1}\left(1^{\mathrm{st}}\right.$ November $), \mathrm{D}_{2}, \mathrm{D}_{3}$ and $\mathrm{D}_{4}$. Sowing dates exhibited significant effect on pod length and number of seed per pod. Minimum harvest index was observed under $\mathrm{D}_{4}\left(16^{\text {th }}\right.$ December). Results showed significant influence of sowing dates on seed germination percentage, weight of 100 seed $(\mathrm{g})$ and seed vigour index in pea. Maximum weight of 100 seed $(\mathrm{g})$ was noted in case of $\mathrm{D}_{1}\left(1^{\text {st }}\right.$ November which was significantly higher than $D_{3}>D_{4}$. While minimum weight of 100 seed $(\mathrm{g})$ was recorded under $\mathrm{D}_{4}$. Maximum germination percentage was observed under $\mathrm{D}_{1}\left(1^{\text {st }}\right.$ November $)$ which was followed by $D_{2}>D_{3}>D_{4}$ while minimum germination (\%) was recorded with $D_{4}$. Maximum seed vigour was recorded with $D_{1}\left(1^{\text {st }}\right.$ November $)$ which was significantly superior over other dates of sowing. Highest number of pods per plant, harvest index, seed yield per plant $(\mathrm{g})$ and seed yield per hectare was found with variety $\mathrm{V}_{7}$. Highest seed yield per plant $(\mathrm{g})$ and seed yield per hectare was recorded with variety $\mathrm{V}_{7}$. Maximum pod length and number of seed per pod was found with $V_{3}$ which was significantly superior over all other varieties. Quality traits of pea significantly influenced sowing dates on seed germination percentage, weight of 100 seed $(\mathrm{g})$ and seed vigour index which were maximum with variety $\mathrm{V}_{7}$ (Kashi Samarth), while lowest were observed in case of variety $\mathrm{V}_{6}$ (Arka Ajit).

\section{Introduction}

Pea (Pisum sativum L.), is being recognized as an important protein supplement vegetable crop. Pea is highly nutritive and contains digestible protein (7.2 g), carbohydrate (15.8 $\mathrm{g})$, vitamin-C (9 mg), phosphorus (139 mg) per $100(\mathrm{~g})$ of edible portion (Gopalakrishnan,
2007). Fresh seed and pea pods can be used as a fresh vegetable or consumed as a frozen product. Dry seeds are used as pulse for human consumption.

Early cultivation of pea was for pulse purpose and mostly round seeded varieties were grown mainly as a rainfed crop. The vegetable pea 
varieties are sweet in taste and hence are mostly wrinkled or dimpled because of high sugar content.

Pea cultivation is widespread in areas having a mild and warm climate, because relatively high or low temperatures are the most important factors limiting pea cultivation. A dry climate is also unsuitable for the plant, particularly during flowering and pod development. Cumulative mean temperature requirements for floral initiation varied and this data could be used to decide sowing dates for different cultivars. Yield can be increased by early sowing and with the use of the seeds of early flowering and maturing cultivars. However, another important factor determining the sowing time and cultivar is the required product (Bozoglu et al., 2007)

Peas are sown in Rabi season from beginning of October to the end of November in northern plains as the cool climate of about four months is ideal for pea growing. The areas where there is slow transition from cool to warm weather are ideal for pea growing. The optimum temperature for seed germination is about $22^{\circ} \mathrm{C}$ however, it can germinate up to $5^{\circ} \mathrm{C}$ but at slow rate. Peas grow best at mean temperature of $13-18^{\circ} \mathrm{C}$. It is tolerant to frost at early stage of growth. At later stage, the flowers and pods are affected. The wrinkled seeded cultivars are more sensitive to high temperature and a temperature of $30^{\circ} \mathrm{C}$ and above even for a day affects the quality of pods. Since the seed crop of garden pea remains in the field for a longer duration, it is very much affected by the sowing time (Singh and Singh, 2011).

Seed yield is affected very much by environmental factors prevailing at the time of seed development. Even at the same location seed yield of early, mid or late maturing pea crops is different because of varying environmental conditions at the time of pod maturity. It is evident from the study that the pea cultivars differ in their yield potential and adaptability to various climatic conditions (Amjad and Anjum, 2002).

Malwa region of Madhya Pradesh is not a traditional area of pea cultivation. But now days with increasing urbanization and growing awareness for vegetable consumption, demand for pea is increasing. Hence, there is a need to enhance the availability of pea by increasing the pea cultivation which requires supply of good quality seed of suitable varieties. Keeping above facts in view, an experiment was carried out to study the effect of date of sowing and varieties on growth, yield and quality of seed in pea.

\section{Materials and Methods}

A field experiment entitled 'Assessment of sowing dates and varieties on growth, yield and quality of seed in garden pea (Pisum sativum L.)' was conducted at Research Field Department of Vegetable Science, College of Horticulture, Mandsaur, RVSKVV, Gwalior (M.P.) during Rabi season in 2014-15. Twenty eight treatment combinations comprising of four different sowing dates viz., $\left(\mathrm{D}_{1}: 1^{\text {st }}\right.$ November, $\quad \mathrm{D}_{2}: 16^{\text {th }}$ November, $\quad \mathrm{D}_{3}: 1^{\text {st }}$ December, $\mathrm{D}_{4}: 16^{\text {th }}$ December) and seven varieties viz., $\left(\mathrm{V}_{1}\right.$ : Arkel, $\mathrm{V}_{2}$ : Azad Pea-3, $\mathrm{V}_{3}$ : Pusa Pragati, $V_{4}$ : Kashi Nandini, $V_{5}$ : Mater Ageta-6, $\mathrm{V}_{6}$ : Arka Ajit and $\mathrm{V}_{7}$ : Kashi Samarth) were taken under study to estimate response in growth and yield of garden pea (Fig. 1 and 2). The physical and chemical composition of the experimental soil also have been calculated and given in (Table 1). Nitrogen, phosphorus and potash were applied at the rate of 50:90:50 kg/ha, respectively, seed was sown in lines at a spacing of $30 \times 10$ $\mathrm{cm}$ and covered with soil. Seeds were sown at a depth of 3-4 $\mathrm{cm}$. before sowing; seed was treated with mancozeb + carbendazim @ 2+1g per $\mathrm{kg}$ seed. The applications of thimet, 
dimethoate $30 \%$ EC (1.5ml/litre), chlorpyrifos $20 \%$ EC $(2 \mathrm{ml} / \mathrm{l})+$ Neem oil $(5 \mathrm{ml} / \mathrm{l})$ were done to control the insect pests. Prophylactic spray of mancozeb $75 \% \mathrm{WP}(2 \mathrm{~g} / \mathrm{l})$ and carbendazim $(1 \mathrm{~g} / \mathrm{l})$ was done to check the diseases. Five plants were randomly selected and tagged from each treatment under each replication excluding the border plants. Observation data were recorded on the tagged plants for the growth, yield and quality attributes of garden pea. The data obtained on various observations for each treatment were subject to 'Analysis of variance' as recommended by Panse and Sukhatme (1985).

\section{Results and Discussion}

\section{Growth parameters}

Growth attributes of garden pea viz., plant height, and number of branches, number of leaves, SPAD value, days to $50 \%$ flowering and days to harvesting were recorded during the present investigation. There was significant effect of varieties and sowing dates on all the stages of growth and parameters (Table 2).

It is resulted the sowing dates $D_{1} \quad\left(1^{\text {st }}\right.$ November) has noticed maximum plant height, number of branches number of leaves, SPAD value, earliest $50 \%$ flowering and harvesting at all the growth stages, while minimum sowing dates was recorded in $\mathrm{D}_{4}$ $\left(16^{\text {th }}\right.$ December). Relatively favourable temperature and longer time available for the growth and development under earlier sowing could have promoted the growth of the plants which consequently resulted in early flowering and lesser days to harvesting. Whereas, last date of sowing was followed by low temperature which slow down the growth and consequently took more days for $50 \%$ flowering and harvesting. Similar results were reported by Bozoglu et al., (2007) and Singh and Singh (2011).
There were significant differences among varieties for growth attributes under the experiment. Maximum plant height was found in variety $V_{7}$ (Kashi Samarth) at all the three growth stages (30, 45 and 60 days after sowing), followed by $\mathrm{V}_{6}$ (Arka Ajit), $\mathrm{V}_{3}$ (Pusa Pragati), $V_{2}$ (Azad Pea-3), $V_{4}$ (Kashi Nandini) and $V_{5}$ (Mater Ageta-6) in descending order at all the stages under study. Minimum plant height was recorded in case of $\mathrm{V}_{1}$ (Arkel). These differences in plant height of different varieties could be attributed to their genetic makeup and adaptability to prevailing environmental conditions. These findings are in line with Amjad and Anjum (2002) and Kalloo et al., (2005).

Variety $\mathrm{V}_{7} \quad$ (Kashi Samarth) recorded maximum number of branches per plant at all the stages followed by $V_{3}$ (Pusa Pragati), $V_{2}$ (Azad Pea-3). Minimum number of branches was found with $\mathrm{V}_{6}$ (Arka Ajit). These variations among varieties may be governed by their genetic makeup. Similar findings have been reported by Shaukat et al., (2012) and Tiwari et al., (2014). Maximum number of leaves per plant were found under variety $V_{7}$ (Kashi Samarth) followed by $\mathrm{V}_{3}$ (Pusa Pragati). Minimum number of leaves was recorded with $\mathrm{V}_{6}$ (Arka Ajit). Higher number of branches might have lead to higher number of leaves. These findings are in accordance to those obtained by Ashraf et al., (2011) and Singh and Singh (2011).

Among the varieties, maximum SPAD value was found with variety $V_{7}$ (Kashi Samarth) followed by $\mathrm{V}_{3}$ (Pusa Pragati). While, lowest SPAD value was determined under $\mathrm{V}_{6}$ (Arka Ajit). Higher SPAD value under these varieties might be the result of favourable interaction effect of environmental conditions and their genotype. Variety $\mathrm{V}_{6}$ (Arka Ajit) had taken maximum days to $50 \%$ flowering after sowing followed by $\mathrm{V}_{7}$ (Kashi Samarth), $\mathrm{V}_{3}$ (Pusa Pragati). The difference between $V_{2}, V_{3}$, 
$\mathrm{V}_{6}$ and $\mathrm{V}_{7}$ was non-significant. Minimum days to $50 \%$ flowering after sowing were taken by variety $\mathrm{V}_{5}$ (Mater Ageta-6). These findings are in agreement with Sharma et al., (2013). Variety $\mathrm{V}_{6}$ (Arka Ajit) had taken maximum days to harvesting after sowing, followed by $\mathrm{V}_{7}$ (Kashi Samarth).

The difference between $V_{6}, V_{7}$ and $V_{3}$ was non-significant. Minimum days to harvesting after sowing were taken by variety $\mathrm{V}_{5}$ (Mater Ageta-6). Delayed commencement of $50 \%$ flowering might have been the reason for late maturity consequently number of days to harvesting. Similar findings were also observed by Amjad and Anjum (2002).

\section{Yield parameters and yield}

Yield attributes viz., number of pod per plant, pod length, number of seed per pod, shelling percentage, seed yield per plant (g), seed yield per hectare and harvest index were recorded to evaluate the impact of different varieties and date of sowing in garden pea (Table $3 a, b, c$, d). There was decrease in number of pods per plant with each delay in sowing. Highest number of pods per plant was recorded under $D_{1}$ ( $1^{\text {st }}$ November), followed by $D_{2}, D_{3}$ and $\mathrm{D}_{4}$. The difference between $\mathrm{D}_{1}$ and $\mathrm{D}_{2}$ was nonsignificant. The earlier sowing provided more period for growth and development which consequently resulted in more number of pod per plant. Similar findings have been reported by Munakamwe et al., (2012) and Shaukat et al., (2012).

Sowing dates exerted remarkable influence on pod length and number of seed per pod. There was linear decrease in pod length with every delayed sowing. Maximum length of pod and number of seed per pod was recorded with $\mathrm{D}_{1}$ ( $1^{\text {st }}$ November) which was followed by $\mathrm{D}_{2}, \mathrm{D}_{3}$ and $\mathrm{D}_{4}$. Sowing dates $\mathrm{D}_{2}, \mathrm{D}_{3}$ and $\mathrm{D}_{4}$ were at par to each other. In early sowing the temperature was optimum for plant growth and development which resulted in vigorous plants with long pods due to which more number of seeds per pod. These results are in agreement to the findings obtained by Munakamwe et al., (2012), Shaukat et al., (2012) and Tiwari et al., (2014).

There was decrease in shelling percentage with each delay in sowing. Highest shelling percentage was recorded under $D_{1} \quad\left(1^{\text {st }}\right.$ November). It was followed by $\mathrm{D}_{2}, \mathrm{D}_{3}$ and $\mathrm{D}_{4}$ in descending order. Lowest shelling percentage was recorded under $\mathrm{D}_{4}\left(16^{\text {th }}\right.$ November). The difference between $\mathrm{D}_{1}$ and $\mathrm{D}_{2}$ was non-significant. These findings are in line with those reported by Tiwari et al., (2014).

Table.1 Physical and chemical composition of the experimental soil

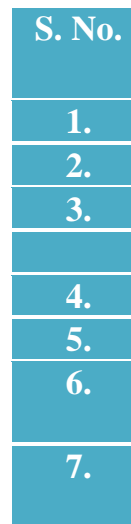

8.

\section{Composition}

Physical

Sand \%

Silt \%

Clay $\%$

Chemical

Soil $\mathrm{pH}$

Electrical conductivity $\left(\mathrm{dSm}^{-1}\right)$

Available nitrogen $(\mathrm{kg} / \mathrm{ha})$

Available phosphorus (kg/ha)

Available potassium (kg/ha)

\begin{tabular}{|c|c|}
\hline Content & Category \\
\hline 55 & - \\
\hline 35 & - \\
\hline 10 & - \\
\hline Content & Category \\
\hline 7.08 & Neutral \\
\hline 0.33 & Normal \\
\hline 317.00 & Medium \\
\hline 19.30 & Medium \\
\hline
\end{tabular}

High

\section{Methods}

Bouyoucos Hydrometer

Bouyoucos Hydrometer

Bouyoucos Hydrometer

Glass electrode pH meter

By conductivity bridge at $25^{0} \mathrm{C}$

Rapid titration method

(Walkley and Black,1934)

Olson's extraction method

(Olson et al., 1954)

Flame photometer

(Ghosh et al., 1981) 
Table.2 Effect of different sowing dates and varieties in growth parameters of garden pea

\begin{tabular}{|c|c|c|c|c|c|c|c|c|c|c|c|c|}
\hline \multirow[t]{2}{*}{ Treatment } & \multicolumn{3}{|c|}{ Plant height (cm) } & \multicolumn{3}{|c|}{$\begin{array}{c}\text { Number of branches of per } \\
\text { plant }\end{array}$} & \multicolumn{3}{|c|}{ Number of leaves per plant } & \multicolumn{3}{|c|}{ SPAD value } \\
\hline & 30DAT & 45 DAT & 60 DAT & 30DAT & 45 DAT & 60 DAT & 30DAT & 45 DAT & 60 DAT & 30DAT & 45 DAT & 60 DAT \\
\hline \multicolumn{13}{|c|}{ Date of Sowing } \\
\hline $\mathrm{D}_{2}$ & 27.46 & 32.70 & 52.18 & 3.58 & 5.82 & 7.54 & 22.23 & 44.97 & 52.46 & 50.01 & 48.33 & 49.42 \\
\hline $\mathbf{D}_{3}$ & 27.42 & 32.31 & 40.88 & 3.51 & 5.57 & 6.83 & 17.60 & 38.02 & 47.17 & 42.47 & 46.02 & 47.30 \\
\hline$\overline{\mathbf{D}_{4}}$ & 26.94 & 32.12 & 40.42 & 3.43 & 5.70 & 6.77 & 17.55 & 37.04 & 45.90 & 32.48 & 44.57 & 45.45 \\
\hline $\mathrm{CD}_{5 \%}$ & 1.42 & 1.48 & 3.88 & 0.34 & 0.56 & 0.60 & 2.01 & 2.81 & 1.85 & 4.25 & 4.43 & 4.01 \\
\hline \multicolumn{13}{|l|}{ Varieties } \\
\hline $\mathrm{V}_{1}$ & 23.21 & 30.18 & 42.43 & 3.57 & 5.73 & 7.59 & 20.50 & 42.46 & 49.58 & 43.59 & 47.41 & 48.83 \\
\hline$\overline{V_{2}}$ & 28.16 & 32.86 & 46.21 & 3.88 & 6.06 & 8.02 & 21.67 & 43.37 & 50.13 & 45.30 & 48.34 & 49.63 \\
\hline $\mathbf{V}_{3}$ & 28.77 & 33.28 & 47.65 & 4.14 & 6.40 & 8.17 & 22.59 & 44.33 & 51.78 & 45.62 & 50.28 & 52.92 \\
\hline$V_{4}$ & 27.15 & 32.15 & 45.22 & 3.21 & 5.63 & 7.36 & 19.83 & 41.42 & 49.17 & 41.93 & 46.28 & 45.24 \\
\hline$\overline{V_{5}}$ & 25.93 & 31.90 & 44.65 & 3.08 & 5.32 & 7.02 & 18.56 & 40.31 & 47.76 & 41.18 & 44.60 & 44.58 \\
\hline$V_{6}$ & 29.38 & 34.16 & 50.77 & 2.97 & 5.44 & 6.31 & 16.98 & 36.63 & 46.12 & 38.25 & 41.04 & 42.57 \\
\hline S.Em \pm & 0.66 & 0.69 & 1.81 & 0.15 & 0.26 & 0.28 & 0.93 & 1.31 & 0.86 & 1.98 & 2.06 & 1.87 \\
\hline $\mathrm{CD}_{5 \%}$ & 1.88 & 1.93 & 5.14 & 0.44 & 0.74 & 0.79 & 2.66 & 3.72 & 2.44 & 5.63 & 5.86 & 5.31 \\
\hline
\end{tabular}

Table.3 (a) Effect of different sowing dates and varieties in yield attributes traits of garden pea

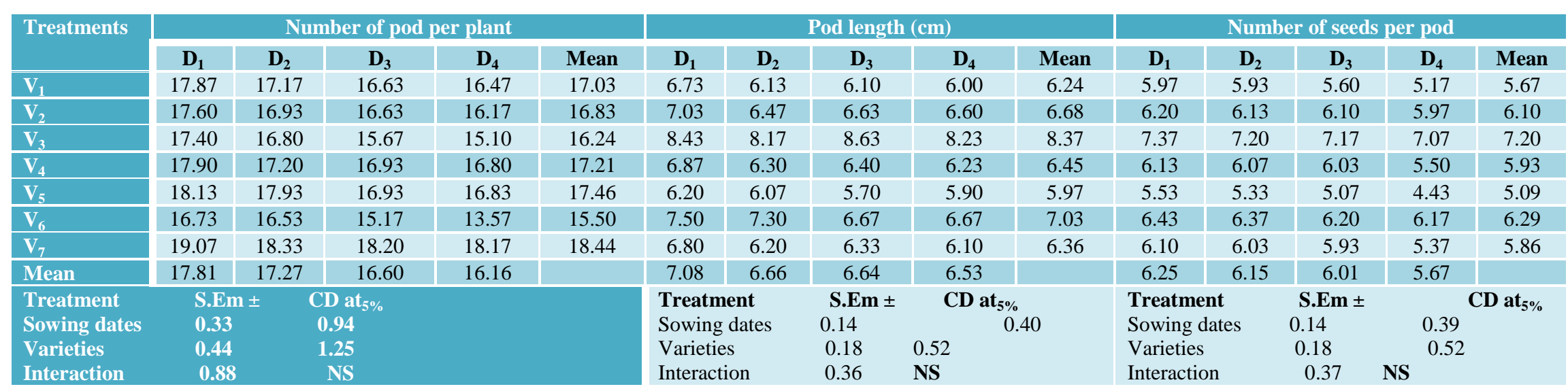


Table.3 (b) Effect of different sowing dates and varieties in yield attributes traits of garden pea

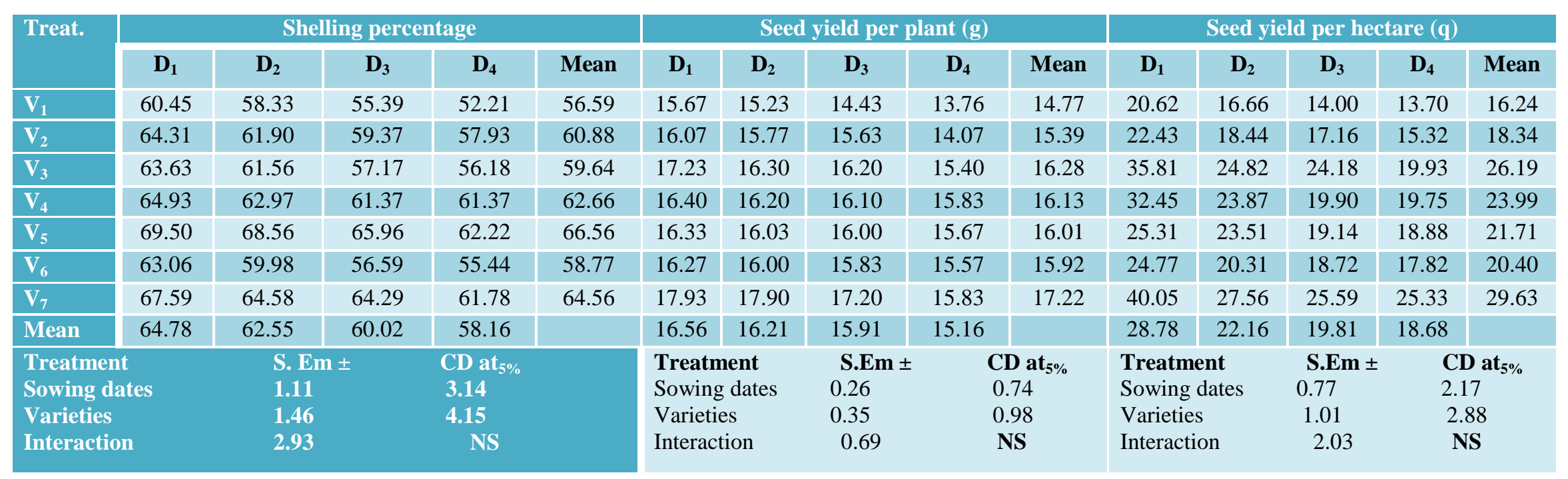

Table.3 (c) Effect of different sowing dates and varieties in yield attributes traits of garden pea

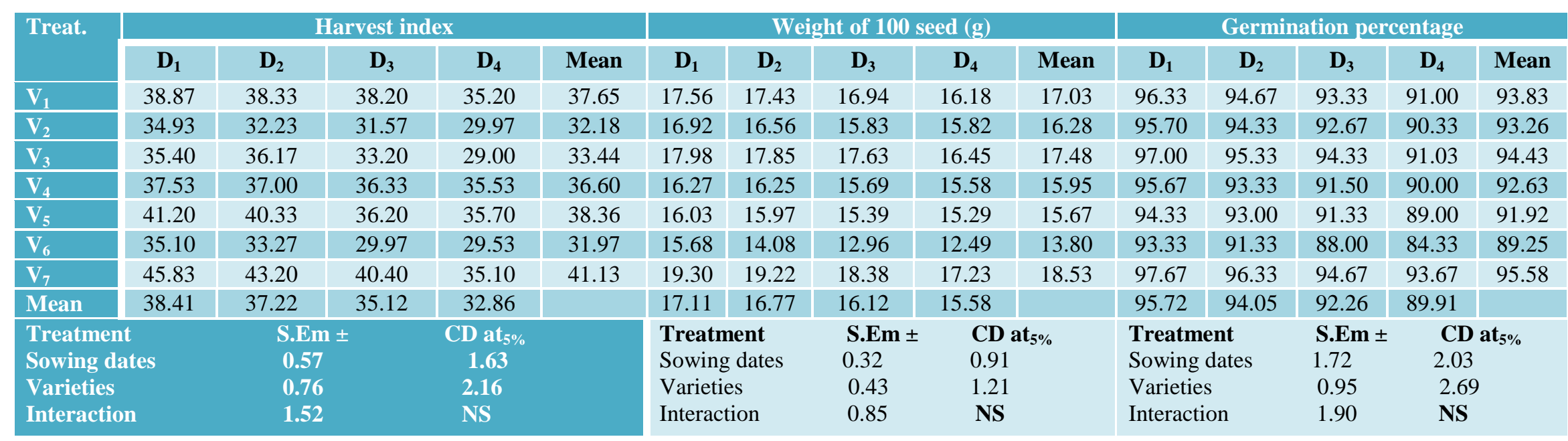


Table.3 (d) Effect of different sowing dates and varieties in yield attributes traits of garden pea

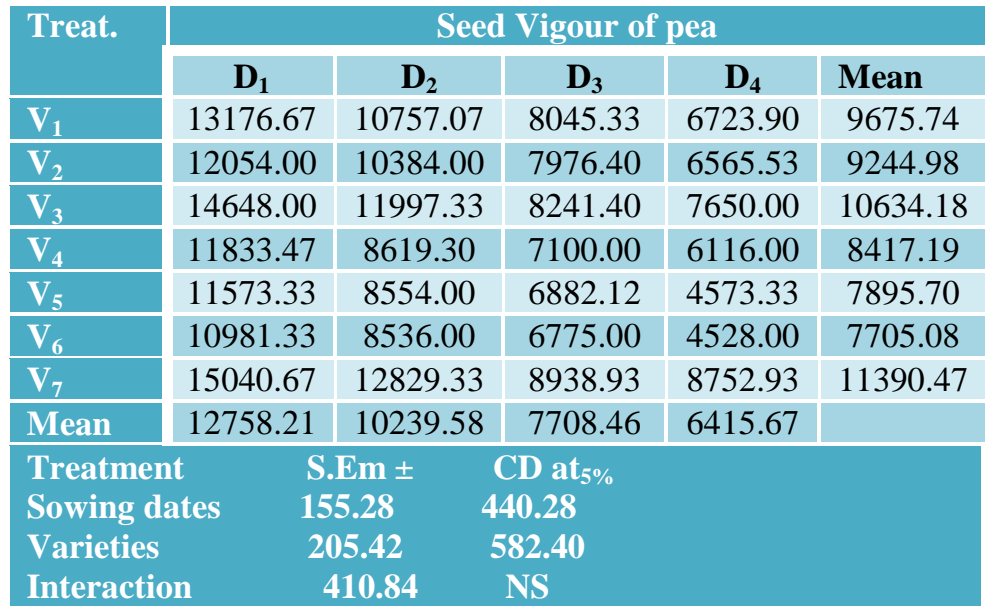

Fig.1 Seeds of different varieties of garden pea

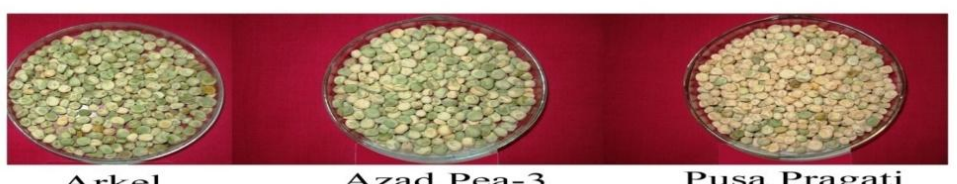

Arkel

Azad Pea-3

Pusa Pragati

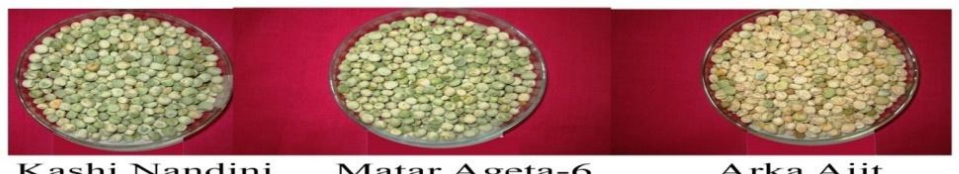

Kashi Nandini Matar Ageta-6 Arka Ajit

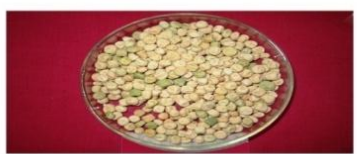

Kashi Samarth

Fig.2 Seeds of garden pea in combination of different date of sowing and varieties

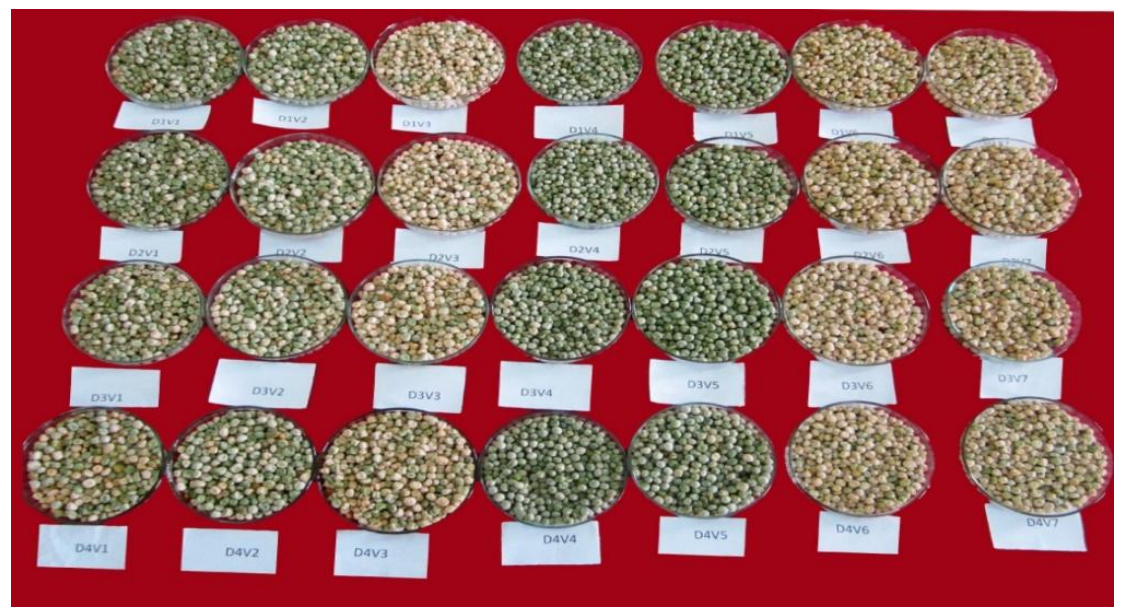


Sowing date exhibited significant influence on seed yield per plant and seed yield per hectare. There was decrease in seed yield per plant and seed yield per hectare with each delayed sowing. Maximum seed yield per plant and seed yield per hectare was recorded with $D_{1}\left(1^{\text {st }}\right.$ November $)$ which was higher than $D_{2}>D_{3}>D_{4}$ sowing dates under study. Favourable effect of earlier sowings on growth and development of pea plants encouraged higher growth and yield attributes which ultimately resulted in higher yield. These findings are corroborated with those reported by Singh and Singh (2011), Munakamwe et al., (2012), Shaukat et al., (2012) and Tiwari et al., (2014).

There was decrease in harvest index with each delayed sowing. Highest harvest index was recorded under $\mathrm{D}_{1}\left(1^{\text {st }}\right.$ November $)$ which was superior over other sowing dates. Minimum harvest index was observed under $\mathrm{D}_{4}\left(16^{\text {th }}\right.$ December). Harvest index under $\mathrm{D}_{1}$ and $\mathrm{D}_{2}$ were at par to each other. Earlier dates of sowing provided more time for growth and development resulting in proper translocation of food material to pod and seeds. Later sowing had lesser time for growth and development thereby might have been forced maturity which could have insufficient development of seed resulting in lower harvest index. Similar findings have been reported by Siddique et al., (2002) and Munakamwe et al., (2012).

Amongst the varieties, highest number of pods per plant was found with variety $\mathrm{V}_{7}$, which was followed by $V_{5}, V_{4}, V_{1}, V_{2}$ and $V_{3}$. Lowest number of pods per plant was observed in case of variety $\mathrm{V}_{6}$. These differences in varieties for number of pods could be ascribed to their genetic makeup as well as favourable effect of environment which promoted growth as well as more number of pods. Similar findings have been reported by Sharma et al., (2013) and Uddin et al., (2014). Pod length and number of seed per pod indicated significant effect of varieties. Maximum pod length and number of seed per pod was found with $V_{3}$ which was significantly superior over all other varieties. Minimum pod length and number of seed per pod was observed in case of variety $\mathrm{V}_{5}$. This variation might be due to the inherent potential of cultivar and their interaction with climatic condition. The number of seed in a pod is variable depending upon the cultivar. These findings are supported with those obtained by Ashraf et al., (2011) and Sharma et al., (2011). Highest shelling percentage was found with variety $V_{5}$, While lowest shelling percentage was observed in case of variety $V_{1}$ (Arkel). The difference between $V_{4}, V_{5}$ and $V_{7}$ was non-significant. These results showed higher food material translocation efficiency of variety $\mathrm{V}_{5}$. These findings are in agreement with Kumari et al., (2008) and Sharma et al., (2011).Highest seed yield per plant (g) and seed yield per hectare was found with variety $\mathrm{V}_{7}$, which was at par to $\mathrm{V}_{3}$ but significantly superior over all other varieties. Similar findings have been reported by Sharma et al., (2013) and Uddin et al., (2014). Variety $\mathrm{V}_{7}$ (Kashi Samarth) registered maximum harvest index which was superior over all other varieties.

\section{Quality parameters}

Quality of pea seed was studied with respect to germination percentage, weight of 100 seed (g) and seed vigour index. Results showed significant influence of sowing dates on seed germination percentage, weight of 100 seed (g) and seed vigour index in pea (Table $3 \mathrm{a}, \mathrm{b}$, c, d). Sowing date exerted significant effect on weight of 100 seed. There was decrease in weight of 100 seed $(\mathrm{g})$ with each delayed sowing. Maximum weight of 100 seed $(\mathrm{g})$ was recorded with $D_{1}\left(1^{\text {st }}\right.$ November which was significantly higher than $\mathrm{D}_{3}>\mathrm{D}_{4}$. While minimum weight of 100 seed (g) was 
recorded under $\mathrm{D}_{4}$. Among the date of sowing, $\mathrm{D}_{1}$ and $\mathrm{D}_{2}$ were at par to each other. These findings are in agreement with Bozoglu et al., (2007) and Singh and Singh (2011). Germination percentage indicated significant effect of sowing dates in pea. There was decrease in germination percentage with each delayed sowing. Maximum germination percentage was recorded with $\mathrm{D}_{1} \quad\left(1^{\text {st }}\right.$ November) which was followed by $D_{2}>D_{3}>$ $\mathrm{D}_{4}$ sowing dates under study while minimum was recorded under $\mathrm{D}_{4}$.

The difference between $\mathrm{D}_{1}$ and $\mathrm{D}_{2}$ was nonsignificant. Similar results were found by Singh and Singh (2011) and Shaukat et al., (2012). Seed vigour was influenced significantly with sowing dates. There was decrease in seed vigour with each delayed sowing. Maximum seed vigour was recorded with $\mathrm{D}_{1}\left(1^{\text {st }}\right.$ November $)$ which was significant superior over other dates of sowing under study. It was followed by $D_{2}>D_{3}>D_{4}$ descending order. All the dates of sowing differed significantly to each other with respect to seed vigour under study. Castillo et al., (2010) had also found significant effect of sowing date on seed vigour in pea.

Among the varieties, maximum weight of 100 (g) seed was found in variety $V_{7}$. These results are in accordance with those reported by Ashraf et al., (2011), Sharma et al., (2013) and Uddin et al., (2014). Maximum germination percentage was found with variety $V_{7}$. Lowest germination percentage was observed in case of variety $\mathrm{V}_{6}$. Among the varieties, maximum seed vigour was found in variety $V_{7}$ which was significantly superior over other dates of sowing under experiment, followed by $\mathrm{V}_{3}$. Lowest seed vigour was observed in case of variety $\mathrm{V}_{6}$. Higher germination (\%) and 100 seed weight resulting from better genetic makeup and growth and development of plant may be the reason for superiority for seed vigour. Similar results were also reported by Kumari et al., (2008) and Ashraf et al., (2011).

\section{Acknowledgment}

The author are highly acknowledged to Director Research Services, Director Instruction, Dean Collage of Agriculture and Head, Department of Vegetable Science, College of Horticulture, Mandsaur (M.P.), Rajmata Vijayaraje Scindia Krishi Vishwa Vidyalaya, Gwalior, Madhya Pradesh, for help in conducting the trial successfully, continuous guidance and technical support during field investigation.

\section{References}

Amjad, M. and Anjum, M. 2002. Performance of nine pea cultivars under Faisalabad conditions. Pak. J. Agri. Sci. 39: 16-19.

Ashraf, M. I., Pervez, M. A., Amjad, M., Ahmad, R. and Ayub, M. 2011. Qualitative and quantitative response of pea (Pisum sativum L.) cultivars to judicious applications of irrigation with phosphorus and potassium. Pak. J. Life Soc. Sci. 9(2): 159-164.

Bozoglu, H., Peksen, E., Peksen, A. and Gulumser, A. 2007. Determination of the yield performance and harvesting periods of fifteen pea (Pisum sativum L.) cultivars sown in autumn and spring. Pakistan J. Bot. 39(6): 2017-2025.

Castillo, A. G., Hampton, J. G. and Coolbear, P. 2010. Effect of sowing date and harvest timing on seed vigour in garden pea (Pisum sativum L.). New Zealand J. Crop Hort. Sci. 22: 91-95.

Kumari, A., Kumar, M. and Kohli, U. K. 2008. Genetic parameters and character association in garden pea cultivars. Veg. Sci. 35 (2): 160-164.

Panse, V. G. and Sukhatme, P. V. 1985. Statistical Method for Agriculture Workers. Fourth edition. ICAR 
Publication, New Delhi.

Sharma, Brij Bihari; Sharma, Vinod Kumar; Dhakar, Mahesh Kumar and Punetha, Shailaja 2013. Combining ability and gene action studies for horticultural traits in garden pea: A review. Afr. $J$. Agric. Res. 8(35): 4718- 4725

Shaukat, S. A., Ahmad, Z., Choudhary, Y. A. and Shaukat, S. K. 2012. Effect of different sowing dates and row spacing on the growth, seed yield and quality of off-season pea (Pisum sativum L. cv. Climax) under temperate conditions of Rawalakot Azad Jammu and Kashmir. Sci. J. Agric. 1(5):117-125.

Singh R. and Singh, P. M. 2011. Effect of sowing dates and varieties on yield and quality of garden pea seed. Veg. Sci. 38(2): 184-187.
Singh, J. P., Singh, D. and Tewari, A. 2012. A comparative study on yield and yield contributing traits of vegetable pea cultivars under Tarai region of Uttarakhand. Pantnagar J. Res. 10 (2): 259-260.

Tiwari, Rajni; Bhatt, Lalit and Dev, Rahul 2014. Effect of date of sowing on growth and yield of vegetable pea genotypes under rain-fed mid-hill conditions of Uttarakhand. Indian $J$. Hort. 71(2): 288-291.

Uddin, Borhan; Paul, A. K., Bari, A S M Fazle; Sultana, Saima and Jahan, M Shah 2014. Effect of different level of Nitrogen and phosphorus on the growth on yield of Garden pea (Pisum sativum L.). Eco-friendly Agril. J. 7(09): 93 -99.

\section{How to cite this article:}

Sonam Sirwaiya and Kushwah, S.S. 2018. Assessment of Different Sowing Dates and Varieties on Growth, Yield and Quality of Seed in Garden Pea (Pisum sativum L.). Int.J.Curr.Microbiol.App.Sci. 7(03): 1387-1396. doi: https://doi.org/10.20546/ijcmas.2018.703.166 